\title{
SIPRI's arms producing and military services companies database
}

\section{Aude Fleurant and Nan Tian}

Aude Fleurant and Nan Tian are, respectively, Director and Researcher at the Arms Transfers and Military Expenditure Programme at the Stockholm International Peace Research Institute, Stockholm, Sweden. She may be reached at fleurant@sipri.org. He may be reached at nan.tian@sipri.org.

\section{Abstract}

This article describes the history of the Stockholm International Peace Research Institute's (SIPRI) arms producing and military services companies database (AIDB) as well as its purpose, its main strengths and deficiencies, and its data collection and implementation processes. It presents ideas to improve the AIDB discussed at an expert workshop held in Stockholm on 23-24 March 2018 and reports on concrete recommendations that SIPRI wishes to take forward to improve the database. The article's first section provides an overview of the database's history. The second section moves on to AIDB's weaknesses and strengths, its data collection approach, and the sources and methods used. Section three discusses deficiencies of the database. Section four details aspects of the expert workshop and the important takeaways from the two-day meeting. The final section offers possible solution approaches to problems with the database.

S IPRI's arms industry database

Arms producing and military services companies - the arms industry, in short-form the supply side of the military market. An integral component of and active agent in that market, they often are national "heavyweight" or "champion" arms producers such as BAE Systems in the U.K., Lockheed Martin in the U.S., and Thales in France. With established close, enduring ties to their respective ministries of defense, they are influential actors when it comes to lobbying for new arms procurement programs. The primary purpose of SIPRI's arms producing and military services companies database (AIDB) is to follow such companies' yearly evolution by presenting their arms sales, describing and analyzing major industry changes, and, when possible, explaining them and their potential consequences. Making the database publicly available, in the form of an annual listing of the top-100 firms, also enables non-SIPRI experts, researchers, and civil society at large to use the data. AIDB is one of the world's few sources to collect and present companies' arms sales figures systematically and consistently. ${ }^{1}$

From a data collection perspective, the arms industry is difficult to delineate. The potential pool of companies involved in arms production is vast and lack of transparency in reporting as well as the absence of an agreed-upon definition of what is an arms sale present obstacles. Since its creation in 1990, a number of conceptual and practical issues have emerged with the top-100 list, notably its limitations regarding coverage, heuristic value, and relevance to peace research. These were discussed at an expert workshop held at SIPRI's offices, 23-24 March 2018.
The arms industry database, part of SIPRI's four core databases, ${ }^{2}$ first published in SIPRI Yearbook 1990, was started in part to support the conversion project - the post-cold war conversion from military to civilian production - and also to reveal "a number of important facts about the structure of this industry" (SIPRI, 1990, p. 325). ${ }^{3}$ It included figures such as companies' arms sales, total sales, arms sales as a share of total sales and the companies' main sector(s) of activities, employment levels, and profits. These and accompanying analyses were presented annually as SIPRI Yearbook chapters until 2002. The effort to collect figures for the supply side of the military market laid the foundations for today's version of AIDB by identifying sources of data and by developing a methodology to estimate companies' arms sales in a rigorously and systematically. Initially, the main purpose was to analyze the post-cold war restructuring of the global arms industry, a goal that is still valid as both the 2000s and the 2010s have seen significant changes in the global arms industry.

By the end of the 1990s, however, a decline in interest in conversion projects led to reduced funding and a publication gap of the top-100 list in the 2003 edition of the Yearbook. But as SIPRI had started to redesign the process and methodology to estimate companies' arms sales, the database was updated, and the figures published, as a new arms industry database as from the Yearbook 2004 onward. (Thus data published in the 2002 and 2004 Yearbooks are not directly comparable.) The 2004 edition of the Yearbook includes firms from ten countries. Methodological caveats were, and still are, numerous, and figures presented were described as "rough." Comparability and coverage were and remain important problems. 
The new version of the AIDB — which is the current version that is updated and published yearly — presents a consistent set of data, following the development of methods to estimate individual companies' arms sales for those that publish problematic figures or those that do not disclose their sales at all. This effort also led to a more diversified collection of sources and increased the pool of potential companies included in the top-100.

Despite improvements, the functionality and uses of AIDB are more limited than those of the other core SIPRI databases. There are enduring issues, for example, the difficulties related to coverage as the arms industry is likely much larger than the top-100 firms, but the resources required to widen the scope of data collection and to augment the current set of companies would be significant. Further, there are gaps in AIDB such as the absence of Chinese firms (discussed below). Additionally, several top-100 companies are privately-held and not required to publish figures related to their military production or services. Frequently, even for companies that do report, the figures presented are questionable or partial.

Several methodological issues arise in using the database. For instance, year-on-year changes in the composition of the top-100 companies tend to occur frequently due to mergers, acquisitions, divestments, bankruptcy, restructuring, and so on . Therefore, the arms sales figures for one company can fluctuate widely over short time frames. The database includes footnotes detailing important variations in arms sales of companies. Another central challenge of the arms industry database is related to the identification of arms sales figures. In the home countries of the top-100 arms companies, national financial authorities may not require that arms companies publish their arms sales figures. There is no agreed-upon definition among the industry and ministries of defense of what is considered an arms and/or military services sale.

SIPRI uses its definition to build arms sales estimates, and it provides figures for incomplete and nonexistent figures when there is enough information to make a rough estimate. For example, some of what SIPRI would consider arms sales often are included in other categories such as intelligence or space, and the military share of these categories needs to be teased out of the sales figures mentioned. Finally, all arms sales are attributed to company headquarters and therefore are linked to the country where the headquarter is located. For large companies with production sites in different countries, the AIDB thus does not reflect where the production occurs. In some cases, when data is available, large subsidiaries are included in the top-100, but do not show up as ranked companies since their revenues already are included in the figures published for the headquarters. This is the case for $\mathrm{BAE}$
This article provides an overview of the history of SIPRI's arms industry and military services companies database (AIDB). It discusses the data collection approach, the sources and methods used, and AIDB's weaknesses and strengths. Further, it reports on an arms industry expert workshop held in March 2018 at SIPRI's offices and on important takeaways from the two-day meeting. Peer-reviewed and edited versions of some of the papers presented at the workshop are published in this special issue of the journal.

Inc., for example, which is the U.S. subsidiary of BAE Systems of the U.K. Despite limitations, the AIDB remains one of the only open sources that provide consistent estimates of arms companies' revenues over time. Offering annual snapshots of the largest arms companies in the world, the definitions and methodology behind the data collection and estimations are available online. ${ }^{4}$

Presenting arms companies by country or region offers insights into a country's or region's military posture, notably the need to retain national arms production capabilities and to avoid dependence on foreign sources of supply for weapons acquisition. For instance, AIDB tracks emerging producers' arms sales from countries such as Brazil, India, South Korea, and Turkey. This helps scholars, policymakers, and others to understand that domestic demand, success in export markets, and the need to become self-reliant in arms (e.g., South Korea) can play vital roles in driving arms sales.

\section{Arms industry database, methods, and issues}

AIDB provides information on the 100 largest companies ranked by sales of arms and military services in a financial year for the period 2002-16. This includes state-owned enterprises as well as publicly-traded and privately-held companies but excludes manufacturing or maintenance units of the armed services. Companies included are those with activities in the field of military goods and services. While SIPRI publishes details on the top-100 companies' sales, employment levels, and profits, information for about 125 companies are available in its internal database.

\section{Methods}

As mentioned, the original purpose of AIDB shaped not only the definition of arms sales but also the methods used for collecting and processing the data. Since the original purpose was to assess the development and structure of the industry, indicators deemed important were total sales, employment, and profitability. While sufficient to gain an industry overview, in practice, the lack of more detailed information is problematic. For example, in several cases, it is challenging to separate 
domestic arms sales from arms exports or to disaggregate sales by type of arms sold or military services provided.

Since the database relies on publicly available information, the scope of the data and geographical coverage is limited. ${ }^{5}$ Data sources are divided into primary and secondary sources. Primary sources are companies' annual reports and information published on their websites. Secondary sources are news published in the business sections of newspapers, in military journals, and by internet news services specializing in military matters. Press releases, marketing reports, government publications of contract awards, and country surveys also are consulted as ways to triangulate companies" "correct" arms sales figures. For some privately-held companies, which have no legal obligation to provide publicly available annual reports, data are estimates and can be unreliable. In this respect, SIPRI is sometimes contacted by researchers and experts based in different world regions who provide new information or who prepare their own arms sales estimates.

Consistent with the military expenditure database, all data first is collected in local currency and at current prices before conversion into current and constant U.S. dollar values for firms listed in the top-100 list.

\section{Main challenges of the arms industry database}

Although the SIPRI top-100 arms industry database provides an invaluable amount of information for policymakers and scholars, there are drawbacks to the database. For example, "[t]he data on arms sales reflect what a company considers to be the defence share of its total sales. In other cases, SIPRI uses the figure for the total sales of a 'defence' division, although the division may also have some unspecified civil sales." 6

Inconsistency in the way companies report

Unlike SIPRI's arms transfers or military expenditure databases, one of the first problems with the arms industry database, given SIPRI's definition of arms sales, is that there is no consistency in the way companies in the industry report such sales. Figures presented by companies differ substantially both between companies and from SIPRI's definition and thus comparison between companies can become problematic.

\section{Double-counting}

Another issue is that looking at companies' arms sales involves some double-counting. As arms companies become more globalized (e.g., globalization via the subsidiaries of large arms producers such as BAE Systems) and weapons are of higher technology, components often are sold between companies so that sales are counted more than once. In a hypothetical example, the sale of an F-35 combat aircraft by Lockheed Martin contains engines from Pratt and Whitney (a subsidiary of United Technologies, the 11th ranked company by arms sales in the 2016 top-100 list) and avionics from BAE Systems. In collecting sales information for these three companies, Pratt and Whitney and BAE Systems will report sales of these items to Lockheed Martin. Lockheed Martin, in turn, will publish the sale of the F-35 aircraft. Thus, when assessing total arms sales, the avionics and engines are recorded twice.

What is accurate, however, is the value of the arms sales per company. In counting the total sales of the industry, the data provide an important and correct reflection of the separate sales each company makes.

\section{Not all arms sales are captured}

Substantial numbers of sales of arms and military services are missed, and company-specific definitions of what constitutes military goods or services imply a potential underestimate of the figures. Companies like General Electric, Hewlett-Packard, and CACI International mainly focus on military services such as telecommunications and information storage, and the line between arms and non-arms sales can become very blurry.

No information on domestic procurement

In principle, the SIPRI databases should inform each other. Military expenditure, especially the resources dedicated to arms research, development, arms procurement, could serve as an overall indicator of input into the military sector. Arms transfers refer to all the equipment or major weapons that are exported or imported for each country and could also give indications on some arms companies' activities. Thus arms sales, less arms transfers should equal domestic procurement. In practice, however, the database links are tenuous. For example, significant time gaps exist between the time the funding for weapons is funneled into the industry and when it shows as a sale in a company's annual report. This creates uncertainty in establishing direct links between demand and supply. Moreover, the military expenditure and the arms transfers databases have on their own methodologies, and combining them is methodologically challenging. (For a quantitative analysis of the relationship between SIPRI's databases, see the article by Smith and Dunne in this issue of the journal.)

One of the main consequences of the lack of domestic arms procurement data is the inability to assess the role domestic demand plays in the development of an arms industry (see Lopes da Silva, in this issue). Having domestic procurement data allows for an analysis of the determinants of arms imports, the role played by foreign and local markets, and of supplier 
dependency ratios. Improvements to the database to include such a measure would open up new research avenues.

Issues related to coverage and changes in the composition of the database

Many have questioned whether SIPRI should expand its top100 database to include more companies. As it is, the current AIDB is not representative of the entire industry but only of the largest companies. This creates regional biases as smaller arms companies, often located outside the U.S. or Western Europe, are presently excluded.

A more complex issue is the difficulty of following firms' behavior over time. For example, if companies outside the top100 sales threshold merge and subsequently then meet the threshold they would appear in the top-100 list, using either the old or a new name. For this newly listed company, historical pre-merger information would be missing. Given that the database was created to understand the structure and development of the arms industry, the inability to track companies' actions or changes in the industry is a significant drawback. While relatively easy to address, this would require more resources to implement.

\section{Regional bias and the absence of China in the database}

With the emergence of China as not only an economic but also military power, the lack of data on Chinese companies is a serious gap in the database. Given its levels of military spending, relatively high self-dependency, and increasing arms exports, it is safe to assume that if information were available, a number of Chinese arms companies would rank quite high in the SIPRI top-100 list. Companies like the state-owned North Industries Corporation (NORINCO) are known to have sold weapons to countries in Africa (e.g., South Sudan) and any information on arms sales of such companies would greatly improve the arms industry database.

One important consequence of not having Chinese arms companies in AIDB is the possible existence of measurement bias where certain relationships (correlates or causal) may disappear if Chinese sales were included. The data can be seen as having a regional bias away from developing countries and thus relationships found in empirical estimations could be valid only for a group of more industrialized western countries.

Brainstorming about the arms industry database With these problems in mind, the Arms and Military Expenditure Programme at SIPRI invited experts in the field to present papers and participate in a two-day-long discussion and "brainstorming" workshop in Stockholm held on 23-24 March 2018. (Some of the papers appear in this issue of this journal.)
The workshop led to an open discussion about how the data and their analysis could be improved, on possible ways to present issues related to the industry's supply side, how to better frame the arms industry from a peace research perspective, and ways to increase the database's visibility. Numerous suggestions made are relevant and of interest to SIPRI, highlighting the multidimensionality of arms companies' profiles. Some of the suggested improvements in or changes to AIDB covered ideas that can be implemented quickly (e.g., the display of the data in new ways); others will need longer-term research and modification to the whole arms industry project in order to reform it.

Framing the arms industry data in a more peace researchoriented way

Several short-term, easy-to-implement ideas to improve the database were discussed during the workshop. One suggested a comparison between the arms industry and other industrial sectors' sales revenues (see the paper by Herbert Wulf, in this issue). The goal behind such a comparison is to help counteract militaristic narratives that unduly emphasize the economic importance of these companies when, in fact, their relative importance to national GDP and employment is rather small. This could also help highlight the arms industry's unique, strong relationship with the state where headquarters are based and that it provides, of course, the means to wage war.

Another suggested project that gathered interest and could be implemented relatively quickly was to pay more attention to mergers, acquisitions, and divestments, which-given the original purpose of AIDB - the experts considered an important dimension to include. This would include the need to keep records on companies' genealogy. Related to this idea, was a suggestion to examine arms industry supply chains. Additionally, country case studies were mentioned as relatively straightforward and possible to implement within a short time frame.

The third idea was to reframe or place less emphasis on the ranking of companies in the database. It was found that large arms companies (in their annual reports) often use AIDB to promote themselves, showcasing how well they are doing, and how highly-ranked they are as compared to others. Possible ways to make the data release less about an advertisement for the arms companies and more in line with SIPRI's peace research mission on armament and disarmament are needed.

Identifying long-term, structural changes in the arms industry and finding ways to account for these changes

Other recommendations for changes to AIDB and associated analyses led to an exploration of conceptual and structural 
issues. These would take time to implement as this would likely involve new data collection, which also means developing definitions, methods, and new estimates. One approach suggested reconceptualizing the way the arms industry is often depicted, e.g., in terms of a hierarchical structure from large weapons integrators (top of the pyramid) to components producers (lower level of the pyramid). Over time, boundaries between types of activities have become increasingly blurred, and in some cases they may be misleading. Looking at supply chains is one way to investigate how to pinpoint the industry's structure better.

In a similar vein, exploring causes, drivers, and effects of arms industry globalization was deemed a central topic, one on which little open source information exists. Considering the precise nature of its production, the trade controls it is subject to, and the limited number of customers for its products, the arms industry globalization profile differs from civilian sectors in several ways. In the 2000 s, a number of reports and articles were published regarding this issue (framed as "transatlantization" at the time), but since then interest in this structural, long-term change appears to have diminished.

Other proposals suggested exploring just how the industry has expanded from a fairly narrow military orientation to broad security concerns - straddling both spheres - and their consequences such as the militarization of public security with greater uses of means of coercion, for instance. While discussed mainly in the Israeli context, this could be investigated broadly. The relationship between arms companies and the government of the country where their headquarters are based also was mentioned as an interesting topic to develop.

\section{Looking for information on Chinese arms companies}

As mentioned, AIDB currently does not include information on Chinese companies, an omission highlighted at the workshop. Starting with the 2017 version of AIDB, slated for release in December 2018, special mention will be made of any credible information found on the Chinese arms industry. The objective is to assess if any reliable information is available in Chinese sources based on which estimates can be made.

Some of the ideas discussed, notably investigating supply chains, require significant financial resources (hiring of researchers) which, for database development, have been difficult to acquire. In several cases, such as the military-security nexus, data would be difficult to collect. Nevertheless, the workshop identified several enduring issues with the industry as well as research questions that can be shared with the expert community to possibly help develop a new research agenda on the supply side.

\section{Moving forward}

While it is clear that SIPRI's arms industry database is an essential resource in the field of peace and security studies, limitations and flaws exist. As SIPRI looks to improve its databases, the arms industry database is a useful starting point. At the expert workshop, useful discussions were held on topics ranging from the use of the database to its limitations, usability, and possible ways forward. The papers featured in this issue of the journal showcase possible uses of AIDB. They highlight both, strengths and relevance as well as difficulties, limitations, and flaws, and they suggest improvements and, in some cases, significant changes to the database. These range from the inclusion of China as an important part of the database to ideas about calculating domestic arms procurement, issues related to arms industry corruption, and even to a statistical analysis suggesting that AIDB's shortcomings actually may not be as severe as some people believe.

In the end, the fundamental question about what is interesting about the arms industry and why one should care needs to be spelled out and explained with more clarity than before. This is the central starting point for SIPRI to explore new and added dimensions to AIDB, and to highlight its role and influence in the arms market.

Notes

We thank workshop participants for their comments and suggestions as well as an anonymous reviewer who provided helpful comments on a draft of this article.

1. SIPRI's complete database is online and can be accessed at https://www.sipri.org/databases/armsindustry. Another source is DefenseNews top-100 list of defense companies. Although the content of this database is similar to SIPRI's AIDB, there are some stark contrasts. While SIPRI uses open sources to construct its database, DefenseNews collects data in the form of a surveys sent to companies. These surveys are not made publicly available and thus it is impossible to corroborate the accuracy of the information. In addition, DefenseNews uses a different definition of arms sales, one that includes homeland security, which SIPRI does not. Moreover, company comparisons across time are not possible with DefenseNews' list since its figures are not provided in constant prices.

2. The other three are the arms transfers database, the military expenditure database, and the multilateral peace operations database.

3. Arms industry data collection supported European countries' efforts to diversify and/or convert arms companies' activities from military to civilian production at a time when military expenditure and funding for weapons procurement declined in large arms producing countries. 
4. See https://www.sipri.org/databases/armsindustry/sourcesand-methods.

5. Not all countries have arms production capabilities; moreover, the information and coverage of the database is limited due to issues of transparency in countries that do produce arms such as China.

6. Quoted from the definition of the arms industry database on https://www.sipri.org/databases/armsindustry/sources-and-m ethods\#definitions.

\section{References}

[SIPRI] Stockholm International Peace Research Institute. 1990. SIPRI Yearbook. Oxford, UK: Oxford University Press. 